\title{
The Current Study of Cyclo-tetrasaccharide Focused on the Synthesizing System from Starch
}

\author{
澱粉からの生成系を中心とした環状四糖研究の現状
}

\author{
Nishimoto, Tomoyuki \\ Hayashibara Biochemical Laboratories, Inc. 7-7 Amase-minami machi, Okayama 700-0834, Japan \\ FAX: +81-86-231-6738, E-mail: amaseken@ hayashibara.co.jp
}

Key Words: cyclo-tetrasaccharide, 1,6- $\alpha$-glucosyltransferase, isomaltosyl transferase

\begin{abstract}
There are many oligosaccharides synthesized enzymatically. However, these are very few kinds of nonreducing glucooligosaccharides synthesized from starch. Examples of such oligosaccharides are trehalose and cyclodextrins. Cyclotetrasaccharide (CTS; cyclo $\{\rightarrow 6)-\alpha-\mathrm{D}-\mathrm{glc} p-(1 \rightarrow 3)-\alpha$-D-glc $p$ $(1 \rightarrow 6)-\alpha-D-g l c p-(1 \rightarrow 3)-\alpha-D-g l c p-(1 \rightarrow\})$, is also one of the nonreducing glucooligosaccharides. A synthesizing system of this cyclic oligosaccharide from starch was recently found in Bacillus globisporus C11. CTS-synthesizing mechanism controlled by two enzymes and the sequence of the genes encording them were reported in succession. These studies indicate that there is a good possibility of industrial production of CTS and a gene cluster related to the synthesis and transport of CTS is present in microorganisms. This review summarizes the current study of CTS by focusing on the CTS-synthesizing system from starch.
\end{abstract}

要 約

酵素的に合成されたオリゴ糖は数多くあるが、澱粉から合 成される非還元性グルコオリゴ糖は、かなり少数である。その ような糖質の例として、トレハロースやシクロデキストリンが ある。環状四糖 (CTS ; cyclo $\rightarrow 6)-\alpha$-D-glcp- $(1 \rightarrow 3)-\alpha-\mathrm{D}$-glc $p-(1 \rightarrow$ 6)- $\alpha$-D-glc $p$ - $(1 \rightarrow 3)-\alpha-\mathrm{D}-\mathrm{glc} p-(1 \rightarrow\})$ もまた、非還元性グルコオリ ゴ糖の一種である。この環状オリゴ糖の澱粉からの生成系が、 最近、Bacillus globisporus $\mathrm{C} 11$ 株に見出され、二つの酵素が関与 した CTS 生成機構およびそれらの遺伝子構造が相次いで報告さ れた。これらにより、CTS の工業的製造の可能性と CTS の合成 および輸送に関与する遺伝子クラスターの存在が示された。本 レビューでは、澱粉からの環状四糖の酵素的生成系を中心に、 最新の研究結果について記述する。

\section{A. Introduction}

Several investigators have reported the enzymatic synthesis of various cyclic oligosaccharides. Cyclodextrins (CDs; cyclic $\alpha$-1,4-linked D-glucooligosaccharide), which are synthesized by cyclodextrin glucanotransferase (CGTase; EC 2.4.1.19) (1), are the best known cyclic oligosaccharides. Besides cyclodextrins, cycloinulo-oligosaccharide (cyclic $\beta$-2,1-linked D-fructooligosaccharide) $(2,3,4)$ and cycloisomalto-oligosaccharide (cyclodextran; cyclic $\alpha$-1,6-linked D-glucooligosaccharide) $(5,6)$ are also well known. Di-D-fructose dianhydride synthesized by inulin fructotransferase (EC 2.4.1.93) (7-9) is also listed as a cyclic oligosaccharide that consists of two fructose molecules.

Cyclic oligosaccharides are not only chemically stable and resistant to exo-type glycosidases but also show various functions on the basis of their structure. CD molecules have a hydrophobic cavity region to form inclusion compounds (10); therefore, CDs are able to stabilize labile materials, mask odor,
A. はじめに

種々の環状オリゴ糖の酵素合成に関する報告がある。シク ロデキストリン (CDs； $\alpha-1,4-$ 結合からなる環状グルコオリゴ糖) は最もよく知られた環状オリゴ糖で、シクロデキストリングル カノトランスフェラーゼ (CGTase；EC 2.4.1.19)により合成され る(1)。他に、酵素合成された環状オリゴ糖としては、シクロイ ヌロオリゴ糖 ( $(\beta-2,1$-結合からなる環状フラクトオリゴ糖)(2-4)や シクロイソマルトオリゴ糖 (シクロデキストラン ; $\alpha-1,6-$ 結合か らなる環状グルコオリゴ糖)(5,6) がある。イヌリンフラクトトラ ンスフェラーゼ (EC 2.4.1.93) で合成される無水ダイフラクトー スも、フラクトース二分子で構成される環状オリゴ糖である (7-9)。

環状オリゴ糖は化学的に安定であることやエキソ型グリコ シダーゼでは分解できないといった特徴だけでなく、それぞれ の構造に起因する種々の機能を発揮する。CD はその空洞による 包接作用を持っており (10)、不安定な物質の安定化、臭気のマス 
and change viscous or oily compounds into powder. In addition, cyclodextran strongly inhibits water-insoluble glucan synthesis by the glucosyltransferase from Streptococcus mutans (11).

Cyclo-tetrasaccharide (CTS) described in this review is a new cyclic oligosaccharide. The only CTS-producing system so far known is from alternan. The polysaccharide alternan is a unique dextran produced from sucrose by Leuconostoc mesenteroides NRRL B-1355 (12). It is composed predominantly from an alternating sequence of $\alpha$-1,3-linked and $\alpha$-1,6-linked D-glucose residues, with approximately $10 \%$ branching. Côté et. al. tried to obtain an enzyme hydrolyzing alternan in an endofashion from soil microorganisms based on the idea that such an enzyme is also a unique glycosidase. This resulted in the isolation of Bacillus sp. NRRL B-21195 as producer of a novel type of end-glucanase (alternanase) (13). Furthermore, it was found that there is CTS in the reaction mixture containing purified enzyme and alternan (14). This is the first report of a naturally produced CTS. Later they examined the substrate specificity of alternanase and reported that CTS was also produced from panose by the enzyme (15). Recently we obtained several soil microorganisms producing CTS from starch differently from Côté et. $a l$., and investigated the enzymes and gene structure involved in CTS-production of Bacillus globisporus C11 among them .

\section{B. CTS-Producing System from $\alpha-1,4$-glucan in $B$. globisporus C11}

CTS-producing enzymes were purified from culture supernatant of $B$. globisporus $\mathrm{C} 11$. As a result, it was found that CTS is produced by the sequential action of two kinds of enzymes: glucosyltransferase and glucanotransferase (16). The former was a 1,6- $\alpha$-glucosyltransferase (6GT) catalyzing the $\alpha$ -
キングや粘性または油状化合物を粉末にすることができる。さ らに、シクロデキストランは、 $\alpha$-グルコシルトランスフェラー ゼによる不溶性グルカンの生成を強く阻害する(11)。

本レビューで紹介する環状四糖 (CTS) は、新しく見いださ れた環状オリゴ糖である。従来、アルタナンからの CTS 生成系 のみが知られていた。アルタナンは、Leuconostoc mesenteroides NRRL B-1355がスクロースから合成する特殊なデキストランで ある(12)。その基本構造として $\alpha-1,6$ 結合と $\alpha-1,3$ 結合が交互に 結合した直鎖からなり、約 $10 \%$ の分岐も存在する。Côté らは アルタナンを分解する酵素もまた特殊なグリコシダーゼである と考え、土堙分離菌からスクリーニングを行った。その結果、 アルタナンを分解する新規なエンド-グルカナーゼ (アルタナ ナーゼ) 生産菌として Bacillus sp. NRRL B-21195株を得た(13)。 さらに、精製酵素をアルタナンに作用させた時の反応液中に CTS が存在することを見出した(14)。これが、CTS の最初の発 見である。その後、アルタナナーゼの基質特異性について検討 し、パノースもまた本酵素の基質となり CTS が生成することを 報告している(15)。我々は最近 Côté らとは別に、澱粉から CTS を生成する微生物を土壤から複数見出した。それら分離菌のひ とつ、Bacillus globisporus C11 株について CTS 生成に関与する 酵素および遺伝子構造について調べた。

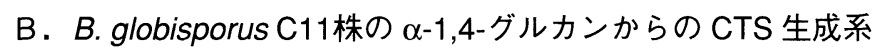
B. globisporus C11 株の培養液上清から酵素を精製したとこ ろ、CTS はグルコシルトランスフェラーゼとグルカノトランス フェラーゼの 2 つの酵素が連続的に作用することで生成するこ とが明らかになった(16)。前者はマルトオリゴ糖 (MOS) の非還 元末端にグルコシル残基 1 分子を $\alpha-1,6$ 転移する反応を触媒し

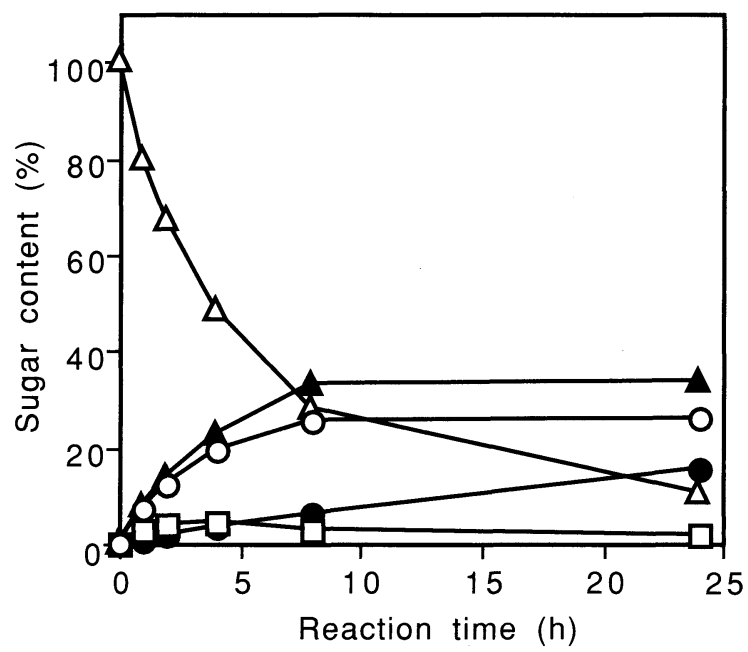

Fig. 1. Changes with time during reaction with maltotetraose by 6GT. A reaction mixture ( $10 \mathrm{ml})$ containing $0.1 \mathrm{~g}$ of maltotetraose and 0.02 unit of $6 \mathrm{GT}$ in $50 \mathrm{mM}$ acetate buffer $\left(\mathrm{pH} \mathrm{6.0)}\right.$ was incubated for the indicated time at $35^{\circ} \mathrm{C}$. The sugar composition was calculated from the peak area of each sugar after HPLC with a YMC-Pack ODS AQ-303 column. $\bigcirc$, maltotriose; $\boldsymbol{O}, \alpha$-isomaltosyl-(1 $\rightarrow 4)$ - $\alpha$-maltose ; $\triangle$, maltotetraose; $\boldsymbol{\Lambda}$, $\alpha$-isomaltosyl-( $(1 \rightarrow 4)$ - $\alpha$-maltotriose; $\square$, maltopentaose. 


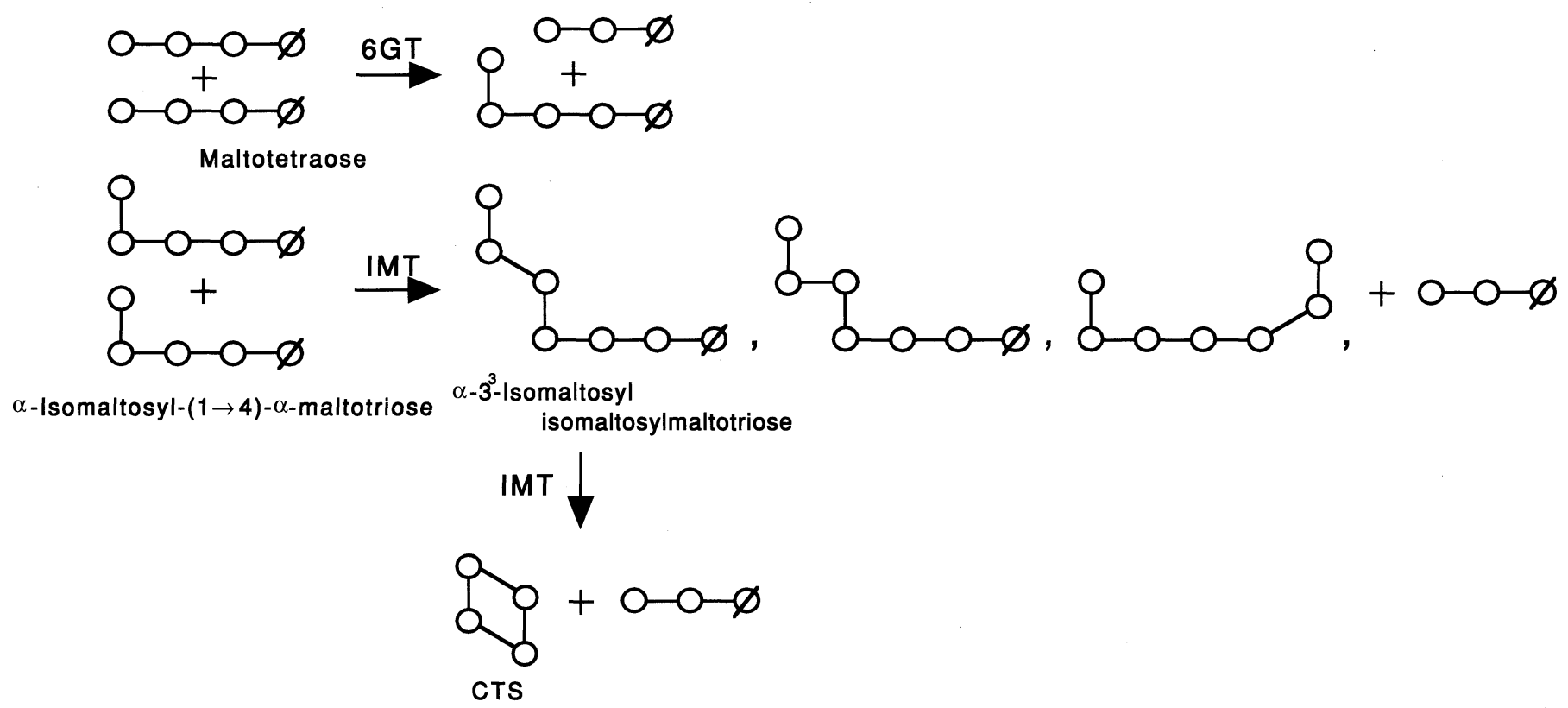

Fig. 2. Scheme for the formation of CTS from maltotetraose by 6GT and IMT. $\bigcirc$, glucosyl residue; $\varnothing$, reducing terminal glucosyl residue; - - $\alpha$-1,4-linkage; $\quad, \alpha$-1,6-linkage; \, $\alpha$-1,3-linkage; $/, \alpha, \beta$-1,1-linkage.

1,6-transglucosylation of one glucosyl residue to the nonreducing end of maltooligosaccharides (MOS) to produce $\alpha$-isomaltosyl-MOS from MOS. The latter was an isomaltosyl transferase (IMT) catalyzing $\alpha-1,3-, \alpha-1,4-$, and $\alpha, \beta-1,1$-intermolecular transglycosylation of isomatosyl residues. In addition, IMT catalyzed cyclization, and produced CTS from $\alpha$ isomaltosyl-( $1 \rightarrow 3)$ - $\alpha$-isomaltosyl-MOS by intramolecular transglycosylation.

Figure 1 shows the change with time during reaction with maltotetraose by 6GT. Alpha-isomaltosl-( $1 \rightarrow 4)-\alpha-$ maltotriose was preferentially synthesized from maltotetoraose and accumulated in the reaction mixture. It was clear that it is hard for this transfer product to become a donor and acceptor of 6GT. These characteristics of 6GT are distinct from those of other glycosidases catalyzing the $\alpha-1,6$-transglucosylation, such as dextrin dextranase (EC 2.4.1.2) and $\alpha$-glucosidase (EC 3.2.1.20) from Aspergillus niger.

When IMT reacted with panose, $\alpha-3^{3}$-isomaltosyl panose, $\alpha-4^{3}$-isomaltosyl panose and $\alpha$-isomaltosyl $\beta$-panoside were synthesized as intermediates of final product CTS. Among the oligosaccharides, $\alpha-3^{3}$-isomaltosyl panose had the highest CTS production rate. Therefore, this oligosaccharide can be considered to be a direct substrate for producing CTS.

Figure 2 shows the scheme of a CTS-producing reaction from maltotetraose. $6 \mathrm{GT}$ provides a favorable substrate to IMT for the production of CTS and IMT synthesizes CTS from this substrate in a 2-step reaction. The reaction leading to CTSproduction was thus organized by a remarkable harmony with 6GT and IMT. The mechanism of conversion of $\alpha-1,4$-gluco-
$\alpha$-イソマルトシル-MOS を生成する 1,6- $\alpha$-グルコシルトランス フェラーゼ (6GT) であった。後者は $\alpha$-イソマルトシル $-\mathrm{MOS}$ の イソマルトシル残基を $\alpha-1,3-、 \alpha-1,4-\alpha, \beta-1,1$ で分子間転移す るイソマルトシルトランスフェラーゼ(IMT) であった。IMT は 環化反応も触媒し、 $\alpha$-イソマルトシル-(1 $\rightarrow 3)-\alpha$-イソマルトシルMOS から分子内転移で CTS を生成する。

6GT をマルトテトラオースに作用させた反応経時変化を図 1 に示す。 $\alpha$-イソマルトシル-(1 $\rightarrow 4)-\alpha$-マルトトリオースが優先 的に生成し、蓄積した。この転移生成物は 6GT の供与体にも受 容体にもなりにくいことがわかった。このような特性は、デキ ストリンデキストラナーゼ (EC 2.4.1.2) や Aspergillus niger 由来 の $\alpha-$ グルコシダーゼ (EC 3.2.1.20) のような、他の 1,6- $\alpha$-グルコ シル転移活性を持つグリコシダーゼと著しく異なる点である。

IMTをパノースに作用させると、CTS 生成の中間体とし て、 $\alpha-3^{3}-$ イソルトシルパノース、 $\alpha-4^{3}$-イソマルトシルパノー スおよび $\alpha$-イソマルトシル $\beta$-パノシドが生成した。これらのオ リゴ糖の中で、 $\alpha-3^{3}$-イソマルトシルパノースからのCTS 生成が 最も速いことから、 $\alpha-3^{3}-$ イソマルトシルパノースがCTS 合成の ための直接の基質であると考えられる。

マルトテトラオースを基質にした場合の CTS 生成反応ス キームを図 2 に示す。6GT は IMT にとって都合のよい基質を提 供し、IMT はこの基質から 2 段階の反応で CTS を生成する。こ のように、6GT と IMT による CTS 生成反応は、両酵素の見事

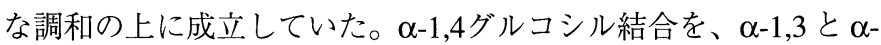


sidic linkage in $\alpha$-1,4-glucan into $\alpha$-1,3- and $\alpha$-1,6-glucosidic linkage was beyond our imagination.

IMT is slightly different from alternanase described above in the effects of calcium ion and EDTA, optimum $\mathrm{pH}$, and the isoelectric point. However, both enzymes are similar in that CTS and glucose are produced from panose (The action on alternan of IMT has not so far been examined.). There is a need to compare IMT with alternanase in detail to judge whether the enzymes are identical.

We examined a distribution of microorganisms having a CTS-producing system similar to B. globisporus C11. Among some 3,000 bacterial strains isolated from soil, Arthrobacter strains producing CTS from starch were obtained. It is interesting that there is also a similar enzymatic system in Arthrobacter strains, except for Bacillus strains. In the future, the difference in enzymes from both strains will be clarified through the study of CTS-producing enzymes from Arthrobacter strains. Such a CTS-producing system may be widely distributed in other microorganisms.

\section{The Structure of Gene Cluster in Bacillus globisporus C11}

The genes for IMT (Cts Y) and 6GT (Cts Z), involved in the synthesis of a CTS have been cloned from the genome of $B$. globisporus C11 (17). The amino-acid sequence encoded by the cts $Y$ gene was composed of 1093 residues having a signal sequence of 29 residues in its $\mathrm{N}$-terminus. The $c t s Z$ gene encoded a protein consisting of 1284 residues with a signal sequence of 35 residues. Both of the gene products showed similarities to aglucosidases belonging to glycoside hydrolase family 31 and conserved two aspartic acids corresponding to the putative catalytic residues of these enzymes (Fig 3). The cts $Z$ gene lay in the rear of the $c t s Y$ gene through a short flanking region of 55 bases. The two genes were linked together, forming cts $Y Z$. A transcription terminator-like sequence lay in the rear of the $C t s Z$ gene.
1,6 結合に変換するというメカニズムは、我々の想像をはるかに 越えるものであった。

IMT は先に述べたアルタナナーゼとカルシウムイオンや EDTA の影響、反応最適 $\mathrm{pH}$ および等電点などが僅かに異なっ ている。しかしながら、両酵素は共にパノースから CTS を生成 するという点で非常に類似した酵素である (IMT のアルタナン に対する作用は検討されていない。)。両酵素が同一の酵素であ るか否かについては、さらに詳細に比較する必要がある。

我々は、本酵素系を持つ微生物の分布について検討した。 およそ土壤分離菌 3,000 株についてスクリーニングした結果、 同様の酵素系を持つArthrobacter 属細菌が見出された。Bacillus 属細菌の他に Arthrobacter 属細菌にも同様の酵素系が存在する ことは興味深い。今後、Arthrobacter 属細菌由来の CTS 生成に 関与する酵素についても性質が調べられ、B. globisporus 由来の 酵素との相違が明らかになるであろう。また、このような酵素 系が他の微生物に広く分布している可能性は十分にあるだろ j。

\section{C．遺伝子クラスター構造}

CTS 生成に関与する IMT 遺伝子 $(C t s Y)$ と 6GT 遺伝子 (Cts Z がB. globisporus C11 株のゲノムからクローニングされた(17)。 $C t s Y$ 遺伝子にコードされるアミノ酸配列は、1,093 残基(分子 量：120,302 Da)で、 $\mathrm{N}$ 末端側に 29 残基からなるシグナル配列 を有していた。CtsZ 遺伝子にコードされるアミノ酸配列は、 1,284 残基 (分子量：139,125 Da) で、 $\mathrm{N}$ 末端側に 35 残基からな るシグナル配列を有していた。両遺伝子産物は糖加水分解酵素

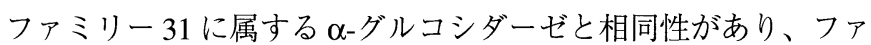
ミリー31の触媒残基と提唱される 2 つのアスパラギン酸も保存 していた(図 3 )。Cts $Z$ 遺伝子は、Cts $Y$ 遺伝子の下流に 55 塩基 対の短いフランキング領域を介して位置していた。このよう に、CTS 合成に関与する 2 つの遺伝子は連結し、CtsYZを形成 していた。CtsZの下流には転写ターミネーター様配列が見出さ れた。今回クローニングされた 16,515 bp の DNA 配列中には、

\begin{tabular}{|c|c|c|}
\hline Enzymes & Region A & Region B \\
\hline CtsW (Bacillus globisporus C11) & 841 - GFKTDGGEF & $938-$ GWDLGGF \\
\hline CtsY (Bacillus globisporus C11) & 562 - GFKTDGGEM & 658 - SWDMAGF \\
\hline CtsZ (Bacillus globisporus C11) & 429 - GWWNDETDK & 531 - GMDTGGF \\
\hline$\alpha-$ Glucosidase (Aspergillus niger) & 486 - GVWYDMSEV & $687-$ GADTCGF \\
\hline$\alpha-$ Glucosidase (Candida tsukubaensis) & 522 - G I WL DMNEP & $769-\mathrm{GADICGF}$ \\
\hline$\alpha-$ Glucosidase (sugar beet) & 465- GI WIDMNEA & $595-G A D I C G F$ \\
\hline Acid $\alpha$-glucosidase (human lysosomal) & 514 - GMWI DMNEP & 643 - GA DVCGF \\
\hline Isomaltase (rabbit intestinal) & 501 - G LWI DMNEV & $631-$ GADICGF \\
\hline
\end{tabular}

Fig. 3. Regional sequence homology among the CTS-forming enzymes and the family 31 -glucosidases. The putative catalytic residues are shadowed. Alpha-glucosidase from Aspergillus niger is the accession number, P56526, in Swiss-prot; from Candida tsukubaensis, P29064; from sugar beet, O04931. Acid- $\alpha$-glucosidase from human lysosome, P10253. Isomaltase (IM) and sucrase from rabbit intestine, P07768. 
The DNA sequence of 16,515 bp cloned in this study contained four open reading frames (ORF1-4) upstream of $c t s Y Z$.

\section{ORF-1 (ctsU)}

ORF-1 was an incomplete ORF missing the 5'-region. The amino-acid sequence (209 residues) deduced from the ORF showed similarities to the $\mathrm{C}$-terminal regions of a hypothetical permease of the sugar transport system encoded by the gene BH1926 from Bacillus halodurans C-125 (18) and a CD-binding protein-dependent permease from Thermococcus sp. B1001 (19). These sequence similarities suggest that the ORF-1 products may be members of the CTS-binding protein-dependent $\mathrm{ABC}$ transport system.

\section{ORF-2 (ctsV)}

ORF-2 lay in the rear of the incomplete ORF-1 through a 98-bp flanking region. The structural gene encoded a protein with 449 amino-acid residues (calculated molecular mass of $49,553 \mathrm{Da}$ ). The putative protein was similar to a CD-binding protein from Thermococcus sp. B1001 (19) and to a periplasmic solute-binding protein of the sugar uptake $\mathrm{ABC}$ transporter from Rhizobium meliloti (20). These sequence similarities suggest that the ORF-2 products may be CTS-binding proteins.

\section{ORF-3 (ctsW)}

ORF-3 encoded a protein with 1237 amino-acid residues not having a signal sequence (calculated molecular mass of $138,846 \mathrm{Da}$ ). The C-terminus amino-acid sequence of the ORF3 protein showed a significant similarity to the $\mathrm{N}$-terminus part of $C t s Y$. The expression experiment showed that the ORF-3 protein produces CTS from panose and not from either 6glucosylated glycogen or starch. It was suggested that the protein is a kind of IMT preferring low-molecular-mass substrates to high-molecular-mass ones. The difference of substrate-preference between ORF-3 protein and IMT may be caused by the lack of the putative sugar-binding C-terminal domain. The ORF3 protein may be an intracellular protein and catalyze another CTS-producing reaction differently from the extracellular IMT.

\section{ORF-4 (ctsX)}

ORF-4 lay between ORF-3 and $c t s Y$ genes, and encoded a small protein of 144 amino-acid residues (16,438 Da). The similarity was insufficient for characterization of the ORF-4 product, and it remains an unknown protein.

As described above, it seems that ctsUVWXYZ is a gene cluster related to CTS (Fig.4). In the case of CDs, cgtBACDE cluster was found in the genome of Thermococcus sp. B1001; $C g t B$ for the intracellular CD-degradation enzyme, $c g t A$ for the extracellular CD-synthesis enzyme (CGTase), $\operatorname{cgt} C$ for the CDbinding protein, $c g t D E$ for the membrane transporter proteins (19). It has been reported that Klebsiella oxytoca M5a1 has a CD-synthesis/uptake/degradation system similar to that of Thermococcus (21).
$C t s Y Z$ の上流に 4 つのオープンリーデイングフレーム (ORF-1〜 4) が存在していた。

\section{ORF-1 (ctsU)}

ORF-1 は、5'-領域が久落した不完全な ORFであった。こ の ORF から推定されるアミノ酸配列 (209残基)は、Bacillus halodurans C-125 由来 BH1926 遺伝子がコードしている糖輸送 系の推定パーミアーゼ (18) や Thermococcus sp. B1001 由来 CD 結合蛋白質依存性パーミアーゼ (19) と相同性を有していた。こ の相同性は ORF-1 蛋白質が CTS 結合蛋白質依存性 ABC トラン スポーター系の一つである可能性を示唆している。 ORF-2 (ctsV)

ORF-2 は、ORF-1 の下流に 98 塩基対のフランキング領域 を介して存在していた。この遺伝子は 449 残基(分子量：49,553 Da)の蛋白質をコードしていた。その推定蛋白は、Thermococcus sp. B1001 由来 CD 結合蛋白質(19) や Rhizobium meliloti 由来糖取 り込み $\mathrm{ABC}$ トランスポーターの periplasmic solute-結合蛋白質 (20)と相同性を有していた。この相同性は ORF-2 蛋白質がCTS 結合蛋白質である可能性を示している。

ORF-3 (ctsW)

ORF-3は、1,237 残基 (分子量：138,846 Da) のシグナル配列 を有しない蛋白質をコードしていた。ORF-3 蛋白質のC 末端ア ミノ酸配列は $C t s Y$ の $\mathrm{N}$ 端部分と高い相同性を持っており、 ORF-3 蛋白質の発現試験を行ったところ、ORF-3 蛋白質はパ ノースから CTS を生成するが、6GT で非還元末端が 6 -グルコ シル化されたグリコーゲンや澱粉には作用しないことがわかっ た。この蛋白質は高分子量基質より低分子量基質を好む IMT の 一種であると考えられた。ORF-3 蛋白質と IMT の基質特異性の 相違は、C末端糖結合ドメイン久落により生じているのかもし れない。ORF-3 蛋白質は菌体内蛋白質で、IMT とは異なる別の CTS 生成反応を触媒している可能性がある。

ORF-4 (ctsX)

ORF-4 は ORF-3 と Cts $Y$ 遺伝子の間に存在し、144アミノ酸 残基 (分子量：16,438 Da) という小さな蛋白質をコードしてい た。ORF-4 蛋白質と明白な相同性は見出されず、その機能はわ かっていない。

このように、cts UVWXYZ は CTS に関連する遺伝子クラス ターを形成していた(図 4 )。CDs の場合、cgtBACDEクラスター $(C g t B$ : 菌体内 $\mathrm{CD}$ 分解酵素、 $\operatorname{cgt} t$ : 菌体外 $\mathrm{CD}$ 合成酵素 (CGTase)、cgtC：CD 結合蛋白質、cgtDE: 膜輸送系蛋白質) Thermococcus sp. B1001 のゲノム中に見出されている。Klebsiella oxytoca M5a1 は Thermococcus と同様、 CD 合成/取り込み/分 解系を持つことが報告されている(21)。 


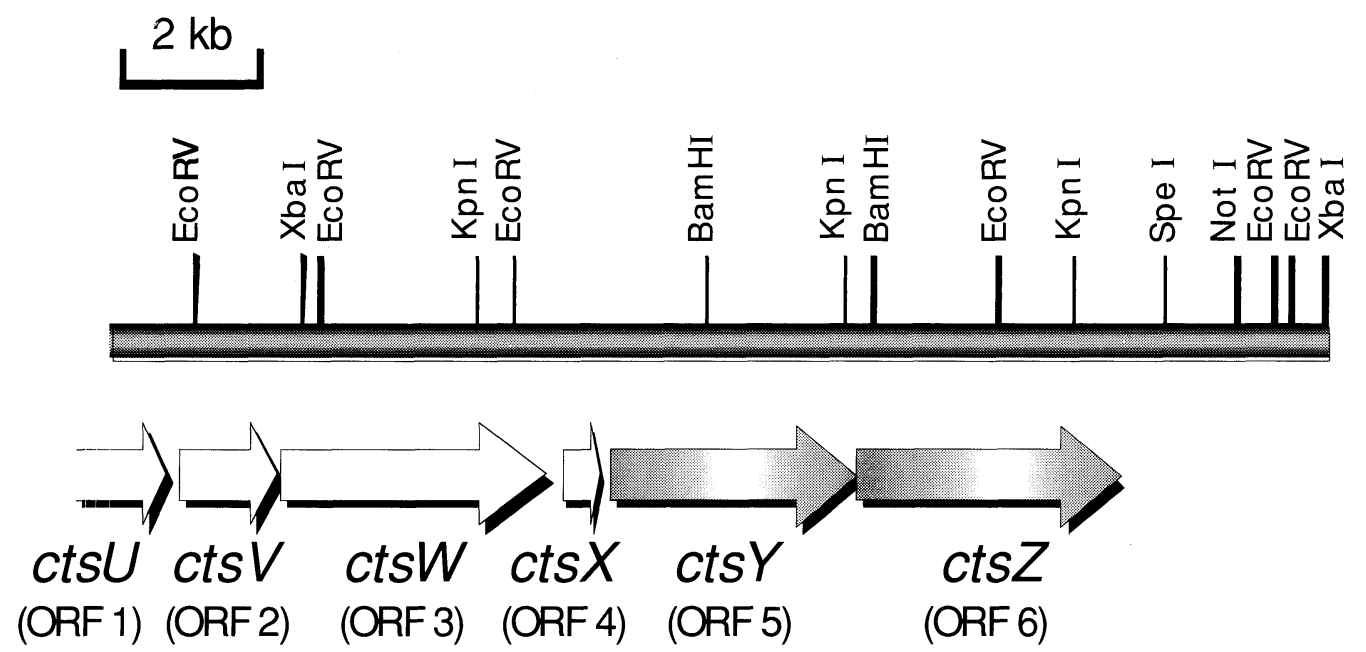

Fig. 4. Structure of the gene cluster containing genes for synthesis and transport of CTS in B. globisporus C11. Arrows show the localization of each gene and the orientation of the coding sequences.

\section{Examination of Reaction Conditions for Synthesizing CTS from Starch}

Since CTS was found, no progress has been accomplished in the study of its applications. The reason seems to be that it has been difficult so far to produce CTS in large quantities and at a low price because alternanase requires particular substrates such as alternan or panose.

Trehalose has been a well-known saccharide for a long time. However, its applications were restricted, because of its high price. A new industrial manufacturing process of trehalose from starch was developed by using two enzymes $(22,23)$, maltooligosyltrehalose synthase (EC 5.4.99.15) and maltooligosyltrehalose trehalohydrolase (EC 3.2.1.141) in recent years. Consequently, the price of trehalose fell drastically. As a result the applications have spread to the food industry, and novel functions of trehalose have become apparent (24). If mass-production method of CTS from inexpensive starch could be developed as in the case of trehalose, the spin-offs would be enormous.

The reaction conditions for CTS synthesis were examined using 6GT and IMT from Bacillus globisporus C11 $(16,25)$. When the substrate is MOS, the yields of CTS increased with the increasing degree of polymerization of MOS (16). Furthermore, when the substrate is partial hydrolyzate of starch, the yields of CTS increased with decreasing hydrolysis percentage (25). Interestingly, glycogen was the most suitable substrate for CTS synthesis and the CTS yields reach $80 \%$ or more. It is known that when the substrates are debranched by isoamylase, the CTS yields decrease significantly. These suggest that the $\alpha-1,6-$ branched structure proves to be favorable to the CTS synthesis (25).

The optimum reaction conditions to obtain CTS from

\section{D．澱粉からの生成条件の検討}

CTS が発見されて以来、その用途に関する研究はあまり進 展していない。これは、CTS の製造にアルタナンまたはパノー スという特殊な基質を要し、そのため大量に安価にCTS を製造 することが困難であるためと考えられる。トレハロースは古く から知られている糖質であるが、高価であったため、その応用 は制限されていた。近年、2つの酵素、マルトオリゴシルトレ ハロースシンターゼ (EC 5.4.99.15) とマルトオリゴシルトレハ ローストレハロハイドロラーゼ (EC 3.2.1.141) による澱粉からの トレハロースの工業的製造法が開発され $(22,23) 、 一$ 挙に価格が 下がり、用途が食品にまで拡大すると共に、新規機能が明らか になった(24)。トレハロースと同様に、CTS の安価な澱粉から の工業的製造法が確立されれば、その恩恵はとても大きい。

B. globisporus $\mathrm{C} 11$ 株由来の $6 \mathrm{GT}$ と IMT を用いた CTS 反応 条件が検討された $(16,25)$ 。基質が MOS である場合、MOS の重 合度が増加するに従いCTS 生成率が高くなり、澱粉部分分解物 の場合、加水分解率が低いほど、CTS 生成率が高くなった。ま た、興味深いことに、グリコーゲンが最もよい基質で、CTS 生 成率は 80 \% 以上になった。反応液にイソアミラーゼを添加し 枝切り処理した場合、CTS 生成率が低下寸ることからも、分岐 構造をもつ方がCTS 生成にはよいことがわかった(25)。

Pinedex \# 100 (澱粉部分分解物 ; 加水分解率 1.5\%)を基質に 
Pinedex\#100 (partial hydrolyzate of starch, 1.3\%-hydrolysis) were the following: substrate concentration, $3 \%$; $\mathrm{pH}, 6-7$; temperature, $30^{\circ} \mathrm{C}$; enzyme dosages, 1 unit/g-dry solid $6 \mathrm{GT}, 10$ units/ g-dry solid IMT. In these optimum conditions the CTS yields reached $62 \%$ at the reaction time of $48 \mathrm{~h}(25)$.

\section{E. Some Properties of CTS}

The CTS crystals are accessible from a water solution $(14,16,25)$. The crystal structure is determined by X-ray analysis (26). The asymmetric unit in the crystal contains one CTS together with five water molecules. One of the water molecules was found in the dish-shape cavity of CTS. CTS adopts a platelike overall shape with a very shallow depression on one side. Accordingly CTS is considered not to have a hydrophobic cavity region to form inclusion compounds similarity to $\mathrm{CDs}$ and CD molecule. Recently, we found CTS anhydrous and monohydrate crystals besides pentahydrate crystals. We are also interested in these crystal structures.

The solubility of CTS pentahydrate crystals in water is relatively high $\left(46.1 \mathrm{~g} / 100 \mathrm{~g}\right.$ water at $\left.20^{\circ} \mathrm{C}\right)$ and the sweetness is $27 \%$ sucrose. CTS does not exhibit maillard reaction at all and is very stable under alkaline conditions because CTS is a nonreducing saccharide (27).

CTS is expected to offer strong resistance to hydrolysis by glycosidases from its structure. In our examination, CTS was finally hydrolyzed to isomaltose by IMT and isomalto-dextranase (EC 3.2.1.94) (The CTS hydrolytic activity of IMT is very weak.). There was a difference between the reaction specificity of the two enzymes. With isomalto-dextranase, an open-chain intermediate was detected in the reaction mixture, while with IMT, this saccharide was not detected. This was probably caused by a difference in the reaction rates of both enzymes on openchain intermediate. This action pattern of alternanase on CTS is analogous to that of IMT (12). Other enzymes hydrolyzing $\alpha$ 1,6-glucosidic linkage in an endo-fashion, such as dextranase (EC 3.2.1.11), isoamylase (EC 3.2.1.68), pullulanase (EC 3.2.1.41) did not act on CTS at all (Nishimoto et. al., unpublished data). No hydrolysis of CTS was observed in an in vitro digestive test using salivary, artificial gastric juice, pancreatic amylases or small intestinal enzymes. CTS was not utilized by typical human intestinal bacteria. These facts indicate that CTS is to a high degree, an indigestive saccharide (27).

\section{F. Enzymatic Synthesis of Branched-CTS Derivatives}

Various derivatives of CDs, representative cyclic oligosaccharide, are synthesized by chemical and enzymatic modifications for additional functions. It is known that $\alpha-1,6$-glycosyl branched $\alpha-\mathrm{CD}$ is synthesized through the condensation of isoamylase and pullulanase to improve the solubility of $\alpha-C D$ $(28,29,30)$.

Two kinds of branched CTS resisting glucoamylase and

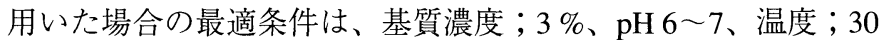
${ }^{\circ} \mathrm{C} 、 6 \mathrm{GT} ； 1$ unit/g-DS、IMT；10 units/g-DS であった。48 時間 反応後の CTS 生成率は $62 \%$ にも達した(25)。

\section{E. CTS の諸物性}

CTS は、水溶液中で容易に結晶化する $(14,16,25)$ 。X線解析 により、その結晶の立体構造が明らかになっている(26)。それに よると、結晶中の CTS 分子は非対称で、 5 つの水分子を持って いる。内、1 分子の水は CTS の空洞の中に存在していた。その ため、全体として浅い窪みを持つプレート状の形をとってい る。従って、CTS 結晶は CDs やシクロデキストランなどの他の グルコ環状オリゴ糖のように包接可能な空洞を持っているわけ ではないようである。最近、我々は上記 5 含水結晶の他にCTS 1 含水㧍よび無水結晶も存在することを確認した。これらの結 晶構造にも興味が持たれる。

CTS 五含水結晶の水に対する溶解度は比較的高く $(46.1 \mathrm{~g} /$ $100 \mathrm{~g}, 20^{\circ} \mathrm{C}$ )、甘味度は砂糖の $27 \%$ である。非還元性糖質であ ることから、メイラード反応は示さないし、アルカリ領域でも 非常に安定である(27)。

CTS はその構造から推定されるように、グリコシダーゼに 対して強い抵抗性を持つことが期待できる。我々が検討した限 り、IMT やイソマルトデキストラナーゼ (EC 3.2.1.94) で最終的 にイソマルトースにまで加水分解された( IMT の CTS 分解活性 は非常に微弱である。）。両酵素の反応特異性には相違点が認め られた。イソマルトデキストラナーゼの場合、開環した中間体 が検出されたが、IMT の場合、この中間体は見出せなかった。 これは、両酵素の中間体に対する作用性が異なるためと考えら れた。アルタナナーゼのCTS に対する作用様式は、IMTによく 似ている(12)。その他、デキストラナーゼ (EC 3.2.1.11)、イソア ミラーゼ (EC 3.2.1.68)、プルラナーゼ (EC 3.2.1.41)などの $\alpha-1,6$ グルコシル結合をエンド型で加水分解する酵素は全く作用しな かった (西本ら、未報告)。唾液、人口胃酸、ブタすい臓アミ ラーゼやラット小腸粘膜酵素を用いたインビトロ消化性試験に おいても全く分解されず、代表的な七ト腸内細菌にも CTS は資 化されなかった。このことから、CTS は非常に高度な難消化性 オリゴ糖であることがわかる(27)。

\section{F．分岐 CTS 誘導体の酵素合成}

環状化オリゴ糖の代表である CDs は、機能性を付加する目 的で化学的挹よび酵素的に修飾された様々な誘導体が合成され ている。溶解度の向上のため、プルラナーゼの縮合反応で合成

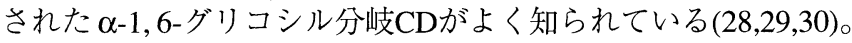
6GT、IMT と澱粉からなる反応液中には CTS の他に、グル 


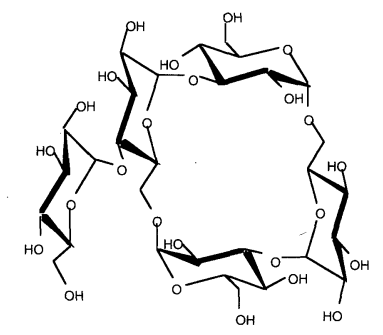

$\alpha-1,4-G l u c o s y l$ branched CTS

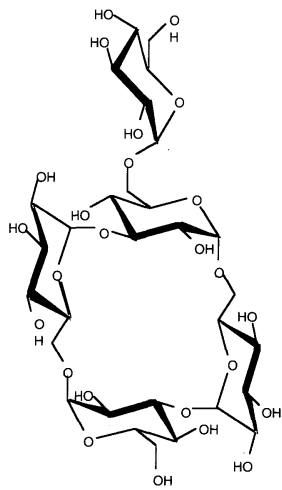

$\alpha-1,6$-Glucosyl branched CTS

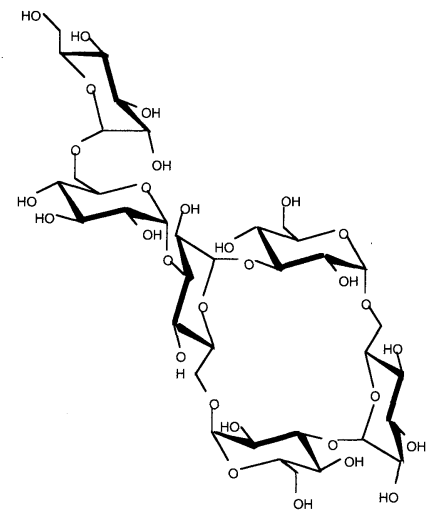

$\alpha-1,3-$ Isomaltosyl branched CTS

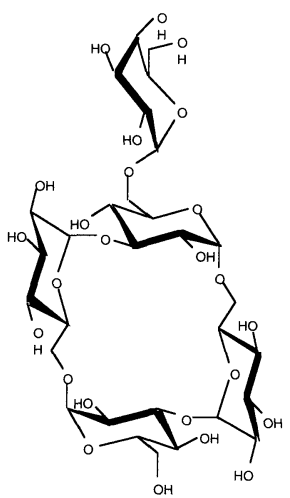

$\alpha-1,6-$ Galactosyl branched CTS

Fig. 5. Structures of branched CTS derivatives synthesized enzymatically.

$\alpha$-amylase were isolated in the reaction mixture containing of 6GT, IMT and starch (25). One is $\alpha-1,4$-glucosyl branched CTS, cyclo $\{\rightarrow 6)-\alpha$-D-glc $p$ - $(1 \rightarrow 3)-\alpha$-D-glc $p$ - $(1 \rightarrow 6)$-[ $[\alpha$-D-glc $p-(1 \rightarrow 4$ )]- $\alpha$-D-glc $p$-( $1 \rightarrow 3)-\alpha$-D-glc $p-(1 \rightarrow\}$ (Fig.5). The other is $\alpha-1,3-$ isomaltosyl branched CTS, cyclo $\{\rightarrow 6)-\alpha$-D-glc $p-(1 \rightarrow 3)-\alpha-\mathrm{D}-$ glc $p-(1 \rightarrow 6)-[\alpha-\mathrm{D}-\mathrm{glc} p-(1 \rightarrow 6)-\alpha-\mathrm{D}-\mathrm{glc} p-(1 \rightarrow 3)]-\alpha-\mathrm{D}-\mathrm{glc} p-$ $(1 \rightarrow 3)-\alpha-D-g l c p-(1 \rightarrow\}$ (Fig.5). These branched CTS are considered to be synthesized by transglycosylation of 6GT and IMT to CTS. On the other hand, Côté and Biely isolated $\alpha-1,6-$ glucosyl branched CTS (Fig.5) from the reaction mixture of alternanase and alternan (14). Such a branched CTS was not observed in the reaction mixture containing 6GT and IMT. This seems to be because there is a difference in enzymes and substrate used.

In addition, enzymatic synthesis of branched CTS is attempted actively. Côté et al. reported that $\alpha$-1,6-galactosyl branched CTS (Fig.5) is mainly synthesized by using $\alpha$-galactosidase from coffee bean and Thermomyces lanuginosus and melibiose as donor substrate (31).
コアミラーゼや $\alpha-$ アミラーゼに耐性の分岐 CTS が主に 2 種生

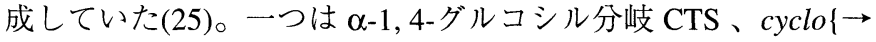
6)- $\alpha$-D-glcp-( $(1 \rightarrow 3)-\alpha$-D-glc $p-(1 \rightarrow 6)-[\alpha-D-g l c p-(1 \rightarrow 4-)]-\alpha$-D-glcp-( $1 \rightarrow$ 3)- $\alpha-\mathrm{D}-g l c p-(1 \rightarrow\}$ (図 5 )である。もう一つは $\alpha-1,3$ イソマルトシ ル分岐 CTS 、 cyclo $\rightarrow 6)-\alpha-\mathrm{D}-\mathrm{glc} p-(1 \rightarrow 3)-\alpha-\mathrm{D}-\mathrm{glc} p-(1 \rightarrow 6)-[\alpha-\mathrm{D}-$ glc $p$ - $(1 \rightarrow 6)-\alpha$-D-glc $p-(1 \rightarrow 3)]-\alpha$-D-glc $p-(1 \rightarrow 3)-\alpha$-D-glcp- $(1 \rightarrow\}($ 図 5$)$ である。これらのオリゴ糖は、6GT と IMT の転移作用により生 成すると考えられている。一方、Côté と Biely はアルタナナー

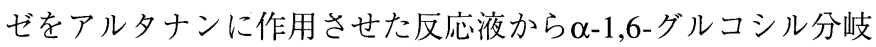
CTS (図 5 ) を単離した (14)。6GT と IMT の酵素系の場合、 $\alpha$ 1,6-グルコシル分岐 CTS は検出されなかった。両者の相違は、 作用する酵素や基質の違いによるものと思われる。

その他、分岐 CTS の酵素合成が積極的に試みられている。 Côté らは、メリビオースを供与体基質としてコーヒー豆および Thermomyces lanuginosus 由来 $\alpha$-ガラクトシダーゼを作用させる ことにより、主生成物として $\alpha-1,6-$ ガラクトシル分岐 CTS (図 5 ) が生成することを報告した(31)。 


\section{G. Prospects}

It is obvious that a starch-degradation pathway controlled by $6 \mathrm{GT}$ and IMT exists in B. globisporus C11. Indeed, during the culture of the strain using soluble starch as carbon source, CTS was synthesized with the decrease of starch in the medium and it was all consumed in time (Nishimoto et. al., unpublished data). This indicates that the strain synthesizes CTS to utilize starch. To clarify the whole starch-degradation pathway in $B$. globisporus $\mathrm{C} 11$, the structure of the gene cluster has to be investigated in further detail. The CTS gene cluster so far clarified is lacking in the genes encoding a part of the $\mathrm{ABC}$ transport system and a CTS-hydrolyzing enzyme.

Extended research is needed for the identification of other functions and applications of CTS. Equally the development of a mass-production method at a reasonable cost is of paramount importance.

Both 6GT and IMT are very attractive enzymes. The distinctive feature of 6GT is that it has a weak hydrolytic activity toward transfer products compared with $\alpha$-glucosidase from $A$. niger using the manufacture of isomalto-oligosaccharides. It is possible that a new manufacturing process of isomalto-oligosaccharides could be achieved using 6GT instead of this $\alpha$-glucosidase. IMT may be able to efficiently synthesize various transfer products having $\alpha$-1,3-glucosidic linkage.

Only about ten years have passed since CTS was found. The study of CTS just begun now, however, and is progressing rapidly. By the time this review is published, new information on CTS will have already been discovered.

\section{G. 今後の展望}

6GT と IMT が関与した澱粉資化経路が B. globisporus $\mathrm{C} 11$ 株に存在していることは明らかである。実際、可溶性澱粉を炭 素源として本菌株を培養すると、港粉の減少と共に培地中に CTS が生成し、やがてそれらが消費された (西本ら、未報告)。 これは、本菌株が澱粉を利用するためにCTS を生成しているこ とを示している。この港粉資化経路の全容を明らかにするため には、その遺伝子構造をさらに検討しなければならない。現在 明らかになっている遺伝子クラスターには、ABCトランスポー ター系の一部、およびCTS 分解酵素に関する遺伝子が不足して いる。

CTS の機能性㧍よび用途を確認するためには、さらなる検 討が必要である。それと共に、CTS を低価格で提供するため、 その工業的製造法の開発も重要である。

6GT、IMT を個々にみた場合、とても魅力的な酵素であ る。6GT は、イソマルトオリゴ糖の製造に使用されているAspergillus niger 由来の $\alpha$-グルコシダーゼよりも転移生成物の分解 活性が低いという特徴を持っている。この酵素の代わりに 6GT を使用することで、イソマルトオリゴ糖の新しい製造方法にな

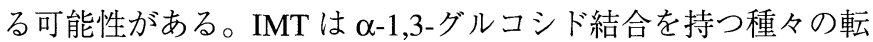
移糖を効率よく合成できるかもしれない。

CTS が発見されてから拉よそ10 年しか経過していない。 CTS の研究は今始まったばかりであるが、研究は急速に進行し ている。おそらく、本レビューが発表されるときには、すでに 新しい情報が発信されているだろう。

\section{References}

1. French, D. (1957) Adv. Carbohydr. Chem. 12, 189-269

2. Kawamura, M., and Uchiyama, T. (1989) Carbohydr. Res. 192, 83-93

3. Kawamura, M., and Uchiyama, T. (1993) Biosci. Biotech. Biochem. 57, 343

4. Kushibe, S., Mitsui, K., Yamagishi, M., Yamada, K., and Morimoto, Y (1995) Biosci. Biotech. Biochem. 59, 31-34

5. Oguma, T., Horiuchi, T., and Kobayashi, M. (1993) Biosci. Biotech. Biochem. 57, 1225-1227

6. Oguma, T., Tobe, K., and Kobayashi, M. (1994) FEBS Lett., 345, 135-138

7. Seki, K., Haraguchi, K., Kishimoto, M., Kobayashi, S., and Kainuma, K. (1989) Agric. Biol. Chem. 53, 2089-2094

8. Ueda, M., Sashida, R., Morimoto, Y., and Ohkishi, H. (1994) Biosci. Biotech. Biochem. 58, 574-575

9. Oguma, T., Horiuchi, T., and Kobayashi, M. (1993) Biosci. Biotech. Biochem. 57, 1225-1227

10. Cramer, F. (1951) Chem. Ber., 84, 851-854

11. Kobayashi, M., Funane, K., and Oguma, T (1995) Biosci. Biotech. Biochem. 59, 1861-1865

12. Côté, G. L., and Robyt, J. F. (1982) Carbohydr. Res. 101, 57-74

13. Biely P., Côté, G. L., and BURGESS-CASSLER, A. (1994) Eur. J. Biochem., 226, 633-639

14. Côté, G. L., and Biely P. (1994) Eur. J. Biochem. 226, 641-648

15. Côté, G. L., and Ahlgren, J. A. (2001) Carbohydr. Res. 332, 373-379

16. Nishimoto, T., Aga, H., Mukai, K., Hashimoto, T., Watanabe, H., Kubota, M., Fukuda, S., Kurimoto, M., and Tsujisaka, Y (2002) Biosci. Biotech. Biochem. 66, 1806-1818

17. Aga, H., Maruta, K., Yamamoto, T., Kubota, M., Fukuda, S., Kurimoto, M., and Tsujisaka, Y. (2002) Biosci. Biotech. Biochem. 66, 10571068

18. Takami, H., Nakasone, K., Takaki, Y., Maeno, G., Sasaki, R., Masui, N., Fuji, F., Hirama, C., Nakamura, Y., Ogasawara, N., Kuhara, S., and Horikoshi, K. (2000) Nucleic Acids Res. 28, 4317-4331

19. Hashimoto, Y., Yamamoto, T., Fujiwara, S., Takagi, M., and Imanaka, T. (2001) J. Bacteriol. 183, 5050-5057

20. Barnett, M. J., Fisher, R. F., Jones, T., Komp, C., Abola, A. P., Barloy-Hubler, F., Bowser, L., Capela, D., Galibert, F., Gouzy, J., Gurjal, M., Hong, A., Huizar, L., Hyman, R. W., Kahn, D., Kahn, M. L., Kalman, S., Keating, D. H., Palm, C., Reck, M. C., Surzycki, R., Wells, D. H., Yeh, K. -C., Davis, R. W., Federspiel, N. A., and Long, S. R. (2001) Proc. Natl. Acad. Sci. U.S.A. 98, 9883-9888

21. Fiedler, G., Pajatsch, M., and Bock, A. (1996) J. Mol. Biol., 256, 279-291 
22. Nakada. T., Maruta, K., Tsusaki, K., Kubota, M., Chaen, H., Sugimoto, T., Kurimoto,M., and Tsujisaka, Y. (1995) Biosci. Biotech. Biochem. 59, 2210-2214

23. Nakada. T., Maruta, K., Mitsuzumi, H., Kubota, M., Chaen, H., Sugimoto, T., Kurimoto,M., and Tsujisaka, Y. (1995) Biosci. Biotech. Biochem. 59, 2215-2218

24. Oku, K., Sawatani, I., Sugimoto, S., Kanbe, M., Takeuchi, K., Murai, S., Kurose, M., Kubota, M., and Fukuda, S. (2002) J. Appl. Glycosci. 49, 351-357 (in Japanese)

25. Aga, H., Higashiyama, T., Watanabe, H., Sonoda, T., Nishimoto, T., Kubota, M., Fukuda, S., Kurimoto, M., and Tsujisaka, Y. (2002) J. Biosci. Bioeng., 94, 336-342

26. Bradbrook, G. M., Gessler, K., Côté, G. L., Momany, F., Biely, P., Bordet, P., Perez, S., and Imberty, A. (2000) Carbohydr. Res., 329, 655-665

27. Shibuya, T., Oku, K., Sawatani, I., Kurose, M., Kubota, M., Fukuda, S., Kurimoto, M., and Tsujisaka, Y. (2002) Abstract book of annual meeting of Japan Society for Bioscience, Biotechnology, and Agrochemistry, 4-2Ga09, Sendai, Japan

28. Abdullah, M., and French, D. (1970) 137, 483

29. Shiraishi, T., Kusano, S., Tsumuraya, Y., and Sakano, Y. (1989) Agric. Biol. Chem. 53, 2181-2188

30. Abe, J. Mizowaki, N., Hizukuri, S., Koizumi, K., and Utamura, T. (1986) Carbohydr. Res. 154, 81-92

31. Biely, P., Puchart, V., and Côté, G. L. (2001) Carbohydr. Res., 332, 299-303

Received on September 14, 2002, accepted on October 7, 2002

\section{Profile of the Authors}

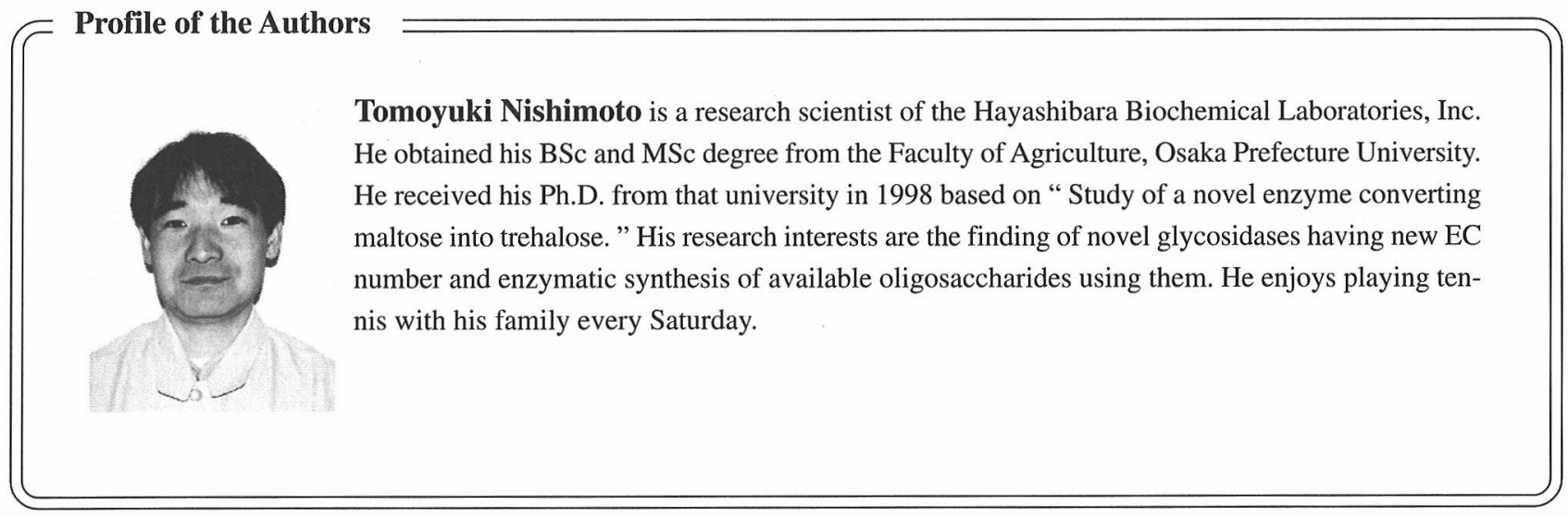

